\title{
Nitrogen Uptake Efficiency and Leaching Losses from Lysimeter-grown Citrus Trees Fertilized at Three Nitrogen Rates
}

\author{
J.P. Syvertsen, and M.L. Smith \\ University of Florida, Institute of Food and Agricultural Sciences, Citrus Research and Education Center, \\ 700 Experiment Station Road, Lake Alfred, FL 33850
}

Additional index words. Citrus paradisi, grapefruit, C. volkameriana, 'Volkamer' lemon, C. aurantium, sour orange, canopy and root growth, evapotranspiration, leaf nitrogen, fruit yield

\begin{abstract}
Four-year-old 'Redblush' grapefruit (Citrus paradisi Macf.) trees on either the relatively fast-growing rootstock 'Volkamer' lemon (VL) (C. volkameriana Ten. \& Pasq.) or on the slower-growing rootstock sour orange (SO) (C. aurantium L.) were transplanted into $7.9-\mathrm{m}^{3}$ drainage lysimeter tanks filled with native Candler sand, irrigated similarly, and fertilized at three $\mathbf{N}$ rates during 2.5 years. After 6 months, effects of $\mathbf{N}$ application rate and rootstock on tree growth, evapotranspiration, fruit yield, $N$ uptake, and leaching were measured during the following 2 years. When trees were 5 years old, low, medium, and high $N$ application rates averaged about 79,180, or $543 \mathrm{~g}$ N/tree per year and about 126,455, or $868 \mathrm{~g} \mathrm{~N} /$ tree during the following year. Recommended rates average about $558 \mathrm{~g}$ N/tree per year. A lysimeter tank with no tree and additional trees growing outside lysimeters received the medium $\mathbf{N}$ treatment. Nitrogen concentration in the drainage water increased with $\mathrm{N}$ rate and exceeded $10 \mathrm{mg} \cdot \mathrm{liter}^{-1}$ for trees receiving the high rates and also for the no tree tank. Leachate $N$ concentration and total $N$ recovered was greater from trees on $S O$ than from those on VL. Average $N$ uptake efficiency of medium $N$ rate trees on VL was 6870 of the applied $N$ and $61 \%$ for trees on SO. Nitrogen uptake efficiency decreased with increased $\mathrm{N}$ application rates. Trees outside lysimeters had lower leaf $\mathrm{N}$ and fruit yield than lysimeter trees. Overall, canopy volume and leaf $N$ concentration increased with $N$ rate, but there was no effect of $N$ rate on fibrous root dry weight. Fruit yield of trees on SO was not affected by $\mathrm{N}$ rate but higher $\mathrm{N}$ resulted in greater yield for trees on VL. Rootstock had no effect on leaf $\mathrm{N}$ concentration, but trees on VI. developed larger canopies, had greater fibrous root dry weight, used more water, and yielded more fruit than trees on SO. Based on growth, fruit yield and N leaching losses, currently recommended $\mathrm{N}$ rates were appropriate for trees on the more vigorous VL rootstock but were $22 \%$ to $69 \%$ too high for trees on SO.
\end{abstract}

The efficient use of fertilizer $\mathrm{N}$ to increase crop yield is an important concern in all agricultural systems. A worthy goal is to maximize $\mathrm{N}$ uptake by the crop while using minimum amounts of fertilizer. This will maximize economic return and minimize residual soil $\mathrm{N}$ that is susceptible to leaching losses, which may contaminate groundwater. In central Florida. where citrus is the most widespread crop, sandy soils and intense rainfall increase the probability that fertilizer $\mathrm{N}$ will leach beyond the root zone. A recent survey of 1031 drinking-water wells sampled in Highlands County, central Florida, found that $29 \%$ had $\mathrm{NO}_{3}-\mathrm{N}$ levels that exceeded the maximum contamination level of $10 \mathrm{mg} \mathrm{N} / \mathrm{liter}$ (Riotte, 1994). Much of this $\mathrm{N}$ contamination has been attributed to citrus production.

Plant growth and yield often are limited by low $\mathrm{N}$ supply. When $\mathrm{N}$ is limiting, plant growth increases with $\mathrm{N}$ concentration in the soil solution, but with diminishing efficiency of uptake (Agren, 1985; Marschner, 1986). Citrus trees with low $\mathrm{N}$ can have a higher $\mathrm{N}$ uptake efficiency than trees with high $\mathrm{N}$ (Smith, 1966a). Citrus tree $\mathrm{N}$ uptake efficiency can be up to $57 \%$ of the $\mathrm{N}$ applied to low$\mathrm{N}$ trees (Dasberg, 1987), and we have measured $\mathrm{N}$ uptake efficiency as high as $68 \%$ of that applied depending on tree growth rate and irrigation water quality (Syvertsen et al., 1993). Since mature citrus trees can store large amounts of $\mathrm{N}$ (Feigenbaum et al., 1986; Kate, 1986), establishing appropriate $\mathrm{N}$ application rates to sustain

Received for publication 15 Dec. 1994. Accepted for publication 19 July 1995. Florida Agricultural Experiment Station Journal series no. R-04298. This research was supported by the Southwest Florida Water Management District (grant no. A6). We acknowledge the technical support of K. Baergen and J. Lea-Cox. The cost of publishing this paper was defrayed in part by the payment of page charges. Under postal regulations, this paper therefore must be hereby marked advertisement solely to indicate this fact. maximum tree growth and fruit yield while minimizing $\mathrm{N}$ losses to leaching can be complex.

Currently recommended $\mathrm{N}$ fertilization rates (Tucker et al., 1995) were formulated to maintain optimum $\mathrm{N}$ concentrations in leaves (25 to $27 \mathrm{mg} \mathrm{N} / \mathrm{g}$ dry weight; Smith, 1966b) of typical trees while maximizing fruit yield and quality. Under uniformly high irrigation and fertilization rates in rootstock trials, rootstock species that produce relatively fast-growing trees (vigorous) also tend to be relatively drought tolerant (Castle et al., 1993; Syvertsen and Lloyd, 1994) and have high concentrations of $\mathrm{N}$ in leaves (Reuther, 1973). Slower-growing trees should require less $\mathrm{N}$ but maybe less efficient at extracting water and $\mathrm{N}$ from the soil. Once accurate $\mathrm{N}$ requirements are defined, it may be possible to modify annual application rates to maximize uptake without overfertilizing. The purpose of these studies was to investigate $\mathrm{N}$ uptake and leaching losses from well-managed citrus trees on two contrasting rootstock which were fertilized at three $\mathrm{N}$ rates. We hypothesized that the $\mathrm{N}$ requirement for tree growth and yield would determine $\mathrm{N}$ uptake efficiency and $\mathrm{N}$ losses to leaching.

\section{Materials and Methods}

Lysimeter tanks and trees. This study was conducted in central Florida using a Candler fine sand soil having a pH of 5 to 6 and $<0.8 \%$ organic matter (Alva and Syvertsen, 1991). Nineteen polyethylene lysimeter tanks, about $3.4 \mathrm{~m}$ in diameter, $0.9 \mathrm{~m}$ deep, and containing about $7.9 \mathrm{~m}^{3}$ of soil, were buried to within $10 \mathrm{~cm}$ above the soil surface. A drainage system of 10 -cm-diameter perforated plastic pipe and a sump pump were placed at the bottom of each tank (Boman and Syvertsen, 1991) to pump drainage water leachate (whenever it accumulated) into 200-liter barrels. The 


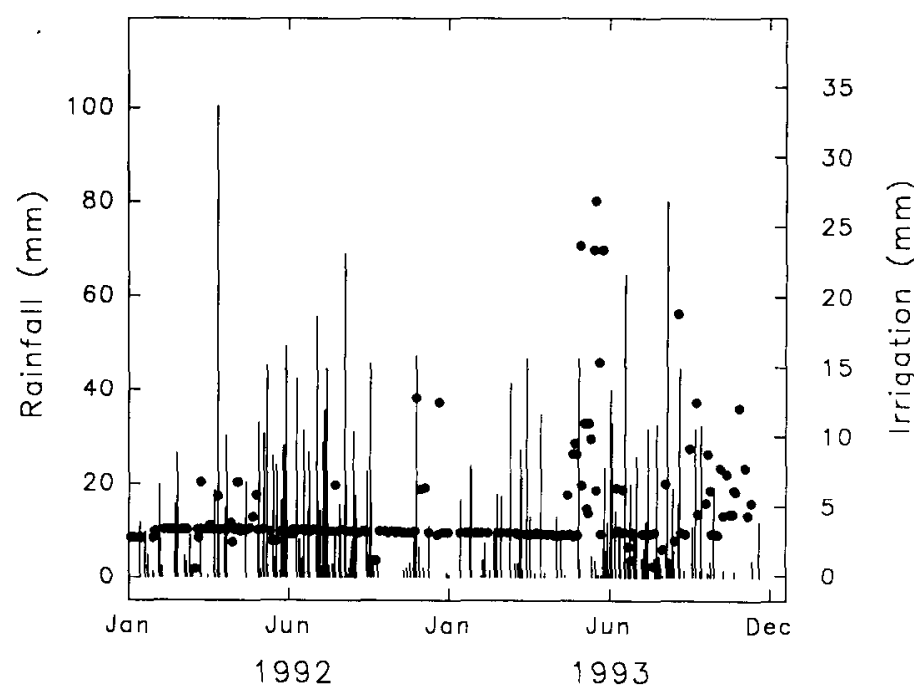

Fig. 1, Average irrigations ( ) that were applied to all treatments and rainfall (1, $\mathrm{mm}$ ) events during 1992 and 1993.

amount of drainage water was measured volumetrically. The soil was back-filled into the tanks to create a uniformly mixed profile similar to the native sand on the site.

Eighteen 4-year-old 'Redblush' grapefruit (Citrus paradisi) trees, nine on 'Volkamer' lemon (VL) (C. volkameriana ) rootstock and nine on sour orange (SO) (C. aurantium) rootstock, were bare-rooted and transplanted individually into 18 tanks during Spring 1991. Lemon rootstock produce some of the fastest growing most vigorous trees (Castle et al., 1993), whereas trees on SO are slower growing and generally have leaves with relatively low N concentrations (Reuther, 1973). Six additional trees (three on each rootstock) were transplanted into soil without lysimeters (no-tank trees). To estimate $\mathrm{N}$ leaching from soil without roots, one additional tank was not planted and designated the no-tree tank. Lysimeter tanks and trees were randomized in two rows at a spacing of $4.9 \mathrm{~m}$ in the row and $6.1 \mathrm{~m}$ between rows, such that tree canopies did not interact. Throughout the study, all soil surfaces were maintained weed free with herbicide and hand cultivation so that no leaf litter accumulated. Trees were sprayed periodically for pests. Trees were well irrigated for 3 months to allow recovery from transplant, and the low, medium, and high $\mathrm{N}$ treatments (described below) were begun in the middle of 1991. The no-tree tank and trees outside tanks were irrigated and fertilized the same as the medium $\mathrm{N}$ rate treatment. All presented data are from years 2 and $3(1992,1993)$ when trees were 5 to 6 years old.

All trees were irrigated similarly at about 0.6 of class A pan evaporation (Dasberg et al., 1991; Whitney et al., 1991) using 60liter $\cdot \mathrm{h}^{-1}$ microsprinklers equipped with downward reelectors that wet a soil surface area of about $3.1 \mathrm{~m}$ in diameter. The irrigation system was scheduled to minimize soil water deficits for the largest trees. Any water applied in excess of soil capacity appeared in the drains. When this occurred, the irrigation frequency was reduced to minimize leaching during the subsequent irrigation interval. About $4 \mathrm{~mm}$ of water was applied in $30 \mathrm{~min}$ at each irrigation (Fig. 1), and the system could be operated for several 30-min intervals per day when evaporative demand was high. Thus, the interval between irrigations varied from $2 \mathrm{~h}$ to 4 days depending on water requirements. Total annual rainfall was 1395 and $1105 \mathrm{~mm}$ during 1992 and 1993, respectively; mean annual rainfall is $1117 \mathrm{~mm}$. When averaged across all treatments, total irrigation water applied during 1992 and 1993 was 347 and $506 \mathrm{~mm} /$ year.

Fertilizer treatments. The $\mathrm{N}-\mathrm{P}-\mathrm{K}-\mathrm{Mg}$ plus microelements were applied about once per week by injecting a liquid (\%) 2-2$8-0.5,6-2-8-0.5$, or $12-2-8-0.5$ into the irrigation system (fertigation) for the low, medium or high $\mathrm{N}$ treatments. The $\mathrm{N}$ source was $\mathrm{NH}_{4} \mathrm{NO}_{3}$. Based on an average tree density of 321 trees/ ha, currently recommended $\mathrm{N}$ rates are about $558 \mathrm{~g} \mathrm{~N} /$ tree per year for typical 5- to 6-year-old trees (Tucker et al., 1995). Actual application rates were calculated from $\mathrm{N}$ samples (described below) of fertigation water and averaged across both rootstock were about $14 \%, 32 \%$, and $98 \%$ of the recommended rate during 1992 (Table I). Each of the three fertigation levels came from a single injection system, so it was only necessary to analyze one sample from each fertigation treatment. Thus, the small differences in $\mathrm{N}$ applied to rootstock were due to slight variations in the water volume applied to each rootstock. Such variations were assumed not to differentially affect results. During Summer 1992, rates were increased so that 1993 applications averaged $23 \%, 82 \%$,

Table 1. Percentage of recommended $\mathrm{N}$, total amount of $\mathrm{N}$ applied, $\mathrm{N}$ leached $(\mathrm{g}, \mathrm{n}=3)$, and the ratio of leached to applied (\%) $\mathrm{N}$ for 5- and 6-yearold 'Redblush' grapefruit trees on 'Volkamer' lemon (VL) or sour orange (SO) rootstock (RS) growing in lysimeter tanks and fertilized at low (L), medium (M), or high $(\mathrm{H}) \mathrm{N}$ rates during 1992-93. Nitrogen concentrations $\left(\mathrm{mg} \cdot \mathrm{liter}^{-1}\right)$ are the average of water samples during each year.

\begin{tabular}{|c|c|c|c|c|c|c|c|c|c|c|c|}
\hline \multirow[b]{2}{*}{$\mathrm{RS}$} & \multicolumn{3}{|c|}{ Recommended N $(\%)^{z}$} & \multicolumn{2}{|c|}{$\mathrm{N}$ applied $(\mathrm{g})^{\mathrm{y}}$} & \multicolumn{2}{|c|}{ N leached (g) } & \multicolumn{2}{|c|}{$\begin{array}{l}\text { Leached : applied } \\
(\%)\end{array}$} & \multicolumn{2}{|c|}{$\begin{array}{l}\text { N leached } \\
\left(\mathrm{mg} \cdot \text { liter }^{-1}\right)\end{array}$} \\
\hline & rate & 92 & 93 & 92 & 93 & 92 & 93 & 92 & 93 & 92 & 93 \\
\hline \multirow[t]{3}{*}{$\overline{\mathrm{VL}}$} & & 14 & 22 & 79 & 120 & 2 & 51 & 2 & 42 & () .2 & 6.7 \\
\hline & & 33 & 85 & 184 & 474 & 4 & 30 & 2 & 6 & 0.5 & 2.4 \\
\hline & & I 03 & 164 & 574 & 916 & 41 & 82 & 7 & 9 & 7.3 & 18.6 \\
\hline \multirow[t]{3}{*}{ SO } & & 14 & 24 & 79 & 132 & 9 & 42 & 11 & 32 & 0.8 & 4.1 \\
\hline & & 31 & 78 & 175 & 436 & 23 & 38 & 13 & 9 & 2.7 & 6.6 \\
\hline & & 92 & 147 & 512 & 820 & 136 & 244 & 27 & 30 & 21.6 & 40.3 \\
\hline No $\operatorname{tree}^{x} M$ & & 33 & 85 & 184 & 474 & 157 & 287 & 85 & 60 & 15.9 & 30.0 \\
\hline \multicolumn{12}{|c|}{ Main effects } \\
\hline \multicolumn{4}{|c|}{$\mathrm{N}$ rate } & & & $* *$ & $* *$ & & & $* *$ & $* *$ \\
\hline \multicolumn{4}{|c|}{ RS } & & & $* *$ & * & & & $* *$ & $* *$ \\
\hline \multicolumn{4}{|c|}{$\mathrm{N} \times \mathrm{RS}$} & & & $*$ & $*$ & & & $* *$ & $* *$ \\
\hline
\end{tabular}

${ }^{\overline{2}}$ Recommended N = 558 g N/year (Tucker et al., 1995).

${ }^{y}$ Values of $\mathrm{N}$ applied were from annual totals of single fertigation samples from each $\mathrm{N}$ treatment.

${ }^{x}$ Single tank with no tree.

Significant at $P<0.05$ or 0.01 . 


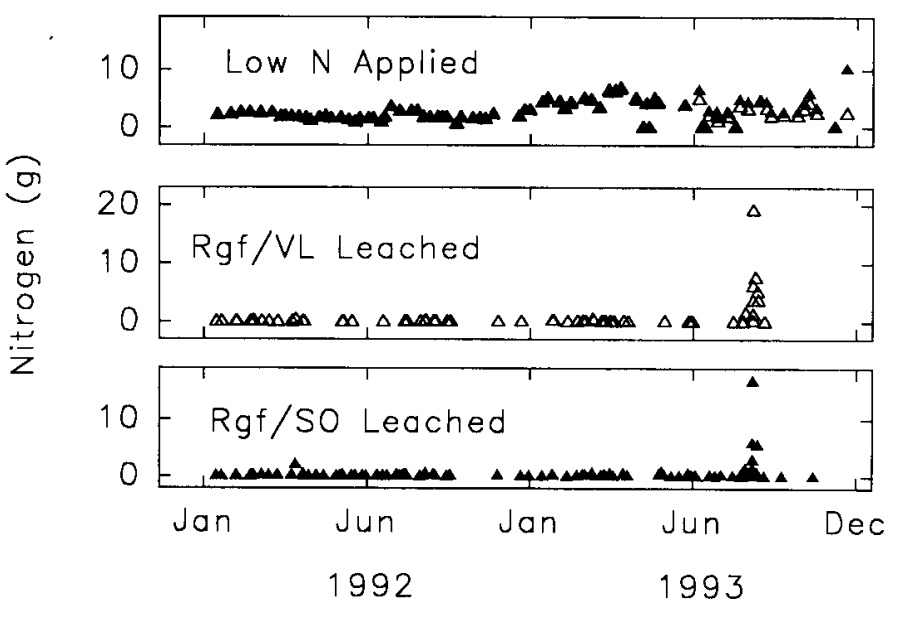

Fig. 2. Weekly amounts $(\mathrm{g})$ of total nitrogen $\left(\mathrm{NH}_{4}+\mathrm{NO}_{3}\right)$ applied and leached into the drainage water from 5-and 6-year-old 'Redblush' grapefruit (Rgf) trees on 'Volkamer' lemon (VL, open symbols) or sour orange (SO, closed symbols) rootstock fertilized at the low rate of $\mathrm{N}(\mathrm{n}=3)$ during 1992 and 1993. Annual totals and statistical analysis appear in Table 1.

and $156 \%$ of the recommended rate. There were 34 fertigations in 1992 and 41 in 1993 injected during a normal 30-min irrigation cycle. Fertigations were scheduled to avoid rainy periods, and splitting the annual fertilizer rate into this relatively high number of applications minimized the nutrient leaching potential (Willis et al., 1990).

Nutrient and water budgets. Volumes of irrigation water applied to each tank were measured with flowmeters, and one 20-ml sample from each of the three $\mathrm{N}$ treatments was analyzed for $\mathrm{NH}_{4}$ and $\mathrm{NO}_{3}$ concentrations using a rapid-flow analyzer (ALPKEM, 1986, 1989). These concentrations were multiplied by the volume of water applied to calculate total $\mathrm{N}\left(\mathrm{NH}_{4}+\mathrm{NO}_{3}\right)$ applied during each year (Table 1). Drainage water samples $(20 \mathrm{ml})$ from each lysimeter were taken as they were pumped into the collection barrels and analyzed for $\mathrm{NH}_{4}$ and $\mathrm{NO}_{3}$. There were 58 sets of 19 leachate samples collected and analyzed in 1992 and 60 sets in 1993. Sample concentrations were multiplied by the total volume pumped to estimate quantities of $\mathrm{N}$ leached below the root zone during the collection period. Only trace amounts of $\mathrm{NH}_{4}$ were occasionally collected in the leachate, so these values were combined with $\mathrm{NO}_{3}$ data and expressed as total $\mathrm{N}$.

Evapotranspiration (ET) for each tank was calculated as the water used between saturating rains by subtracting the volume of the drainage water from the total water input (rainfall plus irrigations). This allowed us to ignore soil water storage. Annual ET was the total water used (in $\mathrm{mm}$ ) based on the $8.8-\mathrm{m}^{2}$ surface area of the lysimeters.

Tree growth and leaf analyses. Tree-trunk circumferences were measured each December and circular trunk cross-sectional areas were calculated. Canopy dimensions were measured five times per year and used to calculate canopy volume as a modified prolate spheroid (Albrigo et al., 1975). In July of both years, twenty 5- to 6-month-old leaves were sampled from around each tree, washed with water, dried at $60 \mathrm{C}$ for at least $48 \mathrm{~h}$, combined into single tree samples, and ground for analysis of total $\mathrm{N}$ (Kjeldahl) and cations (ICPES; Hanlon and DeVore, 1989). Fruit were harvested in December.

Fibrous roots $<2 \mathrm{~mm}$ in diameter were sampled annually during December. Under each tree, one $30 \times 1.8$-cm-diameter soil core sample $\left(76 \mathrm{~cm}^{3}\right)$ was taken from each cardinal directions at distance of 45,90 , and $135 \mathrm{~cm}$ from the trunk and at depths of 0 to
30,31 to 60 , and 61 to $90 \mathrm{~cm}$. Additional soil samples from the notank trees were taken at $180 \mathrm{~cm}$ from the trunk and at a depth of 91 to $120 \mathrm{~cm}$. The four replicate cores from each radius and depth were combined $\left(304 \mathrm{~cm}^{3}\right)$ for analyses. Thus, there were nine (three radii $\times$ three depths) samples from the lysimeter tanks and 16 (four radii $\times$ four depths) samples from the no-tank trees. Structural roots were avoided by resampling an adjacent soil core when woody roots were encountered. Fibrous roots were separated from soil samples by dry sieving and were oven-dried at $60 \mathrm{C}$ for at least $48 \mathrm{~h}$. Root dry weight density in units of $\mathrm{mg} \cdot \mathrm{cm}^{-3}$ of soil sampled was used to calculate a total fibrous root dry weight $(\mathrm{kg})$ per tree by multiplying each root weight density by the soil volume within each radius $\mathrm{x}$ depth. This calculation resulted in progressively weighting root samples from the larger radii (outward from the trunk) more heavily than samples from the smaller radii near the trunk (Syvertsen et al., 1993).

All data from the $\mathrm{N}$ treatment-lysimeter experiment were tested for significant differences using a three $\mathrm{N}$ level $\times$ two rootstock factorial analysis of variance (AOV) with three single-tree replications in a completely randomized design. Effects of lysimeter tanks were tested by AOV using a two treatment (tank vs. no-tank) $\times$ two rootstock factorial AOV within the medium $\mathrm{N}$ treatment. Relationships between selected variables were tested using correlation analysis.

\section{Results}

Leaching losses were generally small from the low (Fig. 2) and medium (Fig. 3) N rates except in mid-September 1993 when several large rain events (Fig. I ) leached relatively large amounts of $\mathrm{N}$. The total annual amount of $\mathrm{N}$ recovered in the drainage water from the three replicate tanks (data shown in Figs. 2-4) was

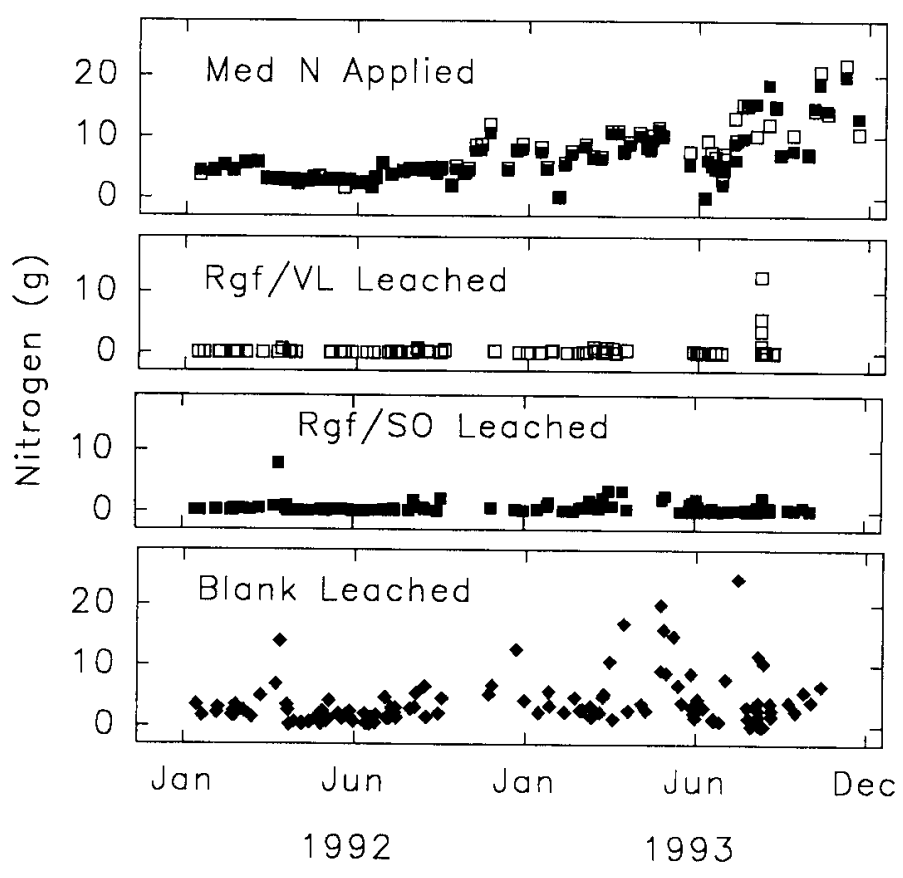

Fig. 3. Weekly amounts $(\mathrm{g})$ ot total nitrogen $\left(\mathrm{NH}_{4}+\mathrm{NO}_{3}\right)$ applied and leached into the drainage water from 5- and 6-year-old "Redblush' grapefruit (Rgf) trees on 'Volkamer' lemon (VL, open symbols) or sour orange (SO, closed symbols) rootstucks fertilized at the medium (med) rate of $N(n=3)$ during 1992 and 1993 The blank tank $\bullet$ ) received the same fertilizer as the VL treatment. Annual totals and statistical analysis appear in Table 1. 

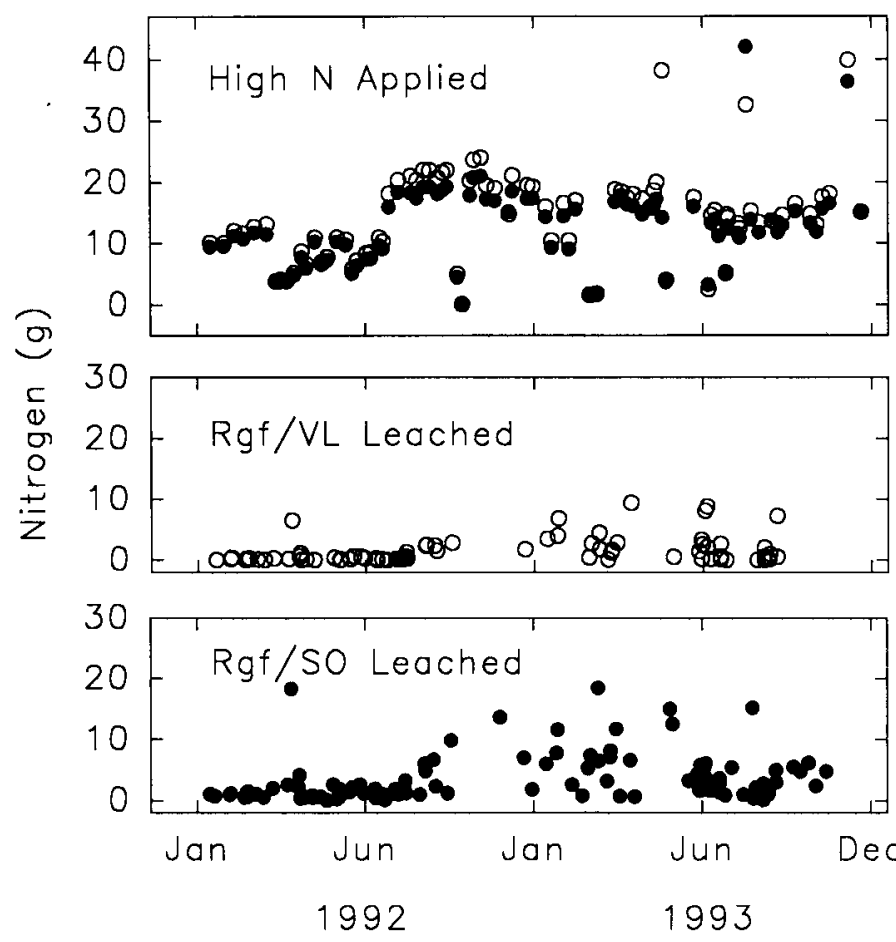

Fig. 4. Weekly amounts $(\mathrm{g})$ of nitrogen $\left(\mathrm{NH}_{4}+\mathrm{NO}_{3}\right)$ applied and leached into the drainage water from 5- and 6-year-old 'Redblush' grapefruit (Rgf) trees on 'Volkamer' lemon (VL, open symbols) or sour orange (SO, closed symbols) rootstock fertilized at the high rate of $N(n=3)$ during 1992 and 1993. Annual totals and statistical analysis appear in Table 1.

divided by the $\mathrm{N}$ applied to calculate an average percentage leached $(\mathrm{N}$ leached/N applied $\times 100)$ for each year (Table 1$)$. In the no-tree tank, the medium $\mathrm{N}$ rate was increased more than 2.5 -fold between 1992 and 1993 (from 184 to 474 g/year), and a smaller percentage of that applied was recovered in 1993 than in 1992 $(60 \%$ vs. $85 \%)$. This doubling of rate was reflected in average leachate concentrations from the no tree tank, 15.9 and $30 \mathrm{mg} \mathrm{N} /$ liter. Relatively small percentages, from $2 \%$ to $9 \%$ of that applied, were leached below trees on VL during the 2 years except for the low $\mathrm{N}$ trees on VL which, in 1993, allowed $42 \%$ of that applied to leach into drainage water. Nonetheless, the average concentration of $\mathrm{N}$ in the drainage water from this treatment was only $6.7 \mathrm{mg} \cdot \mathrm{liter}^{-1}$. In 1992, the high $\mathrm{N}$ rate for trees on VL, which was $103 \%$. of recommended, leached $7 \%$ of that applied and resulted in average $\mathrm{N}$ concentrations of $7.3 \mathrm{mg} \mathrm{N} / \mathrm{liter}$. During 1993, however, 9\% of the high $\mathrm{N}$ (164\% of recommended) was recovered in the drainage water from trees on VL and the average concentration was $18.6 \mathrm{mg} \mathrm{N} / \mathrm{liter}$.

In general, there were greater amounts of $\mathrm{N}$, larger percentages of $\mathrm{N}$ recovered, and higher concentrations of $\mathrm{N}$ in drainage water from trees on SO than from trees on VL, except for low-N trees on VL in 1993 (Table 1). High-N trees on SO leached 27\% and 30\% of the applied N into the drainage water during 1992 and 1993 , which resulted in average concentrations of 21 and $40 \mathrm{mg} \mathrm{N} /$ liter. Medium-N trees on SO receiving 31\% and $78 \%$ of recommended rates lost $13 \%$ and $9 \%$ of the applied $\mathrm{N}$ in drainage water. This resulted in average concentrations of only 2.7 and $6.6 \mathrm{mg} \mathrm{N} /$ liter.

There was a higher total evaporation component of the ET of the no-tree tank in 1992, $999 \mathrm{~mm}$, than in 1993, $755 \mathrm{~mm}$. This was apparently related to the higher rainfall in 1992 than in 1993 that may have contributed to the overall larger ET in 1992 than in 1993 regardless of rootstock or $\mathrm{N}$ treatment (Table 2). Trees on VL had larger ET than those on SO and low N trees had lower ET than high $\mathrm{N}$ trees.

Throughout the 2 years, canopy volumes continued to expand and treatment effects became more pronounced (Fig. 5). Canopy growth for high- and medium-N trees on $\mathrm{SO}$ were similar during the 2 years. Canopy volumes increased with increased $\mathrm{N}$ rates, and trees on VL were larger than those on SO (Table 2). Growing trees inside tanks affected canopy volumes of trees on the two rootstock differently as tank $\mathrm{x}$ rootstock interactions were significant in 1992. Canopies of SO trees outside tanks were smaller than SO medium- $\mathrm{N}$ trees in lysimeters, whereas no-tank VL trees were larger than VL trees in tanks. Trunk cross-sectional areas (data not shown) followed the same patterns as canopy volumes.

Large variations between replicate trees resulted in no significant effects of $\mathrm{N}$ on fibrous root dry weight per tree (Table 2). Nonetheless, there were significant rootstock effects on root dry

Table 2. Evapotranspiration (ET), canopy volume (CV) fibrous root dry weight (RDW), leaf N (LN) concentration, and fruit yield (FY) of 5- and 6year-old 'Redblush' grapefruit trees on 'Volkamer' lemon (VL) or sour orange (SO) rootstock (RS) growing in lysimeter tanks (T) and fertilized with low (L), medium (M), or high (H) N rates or in soil with no tanks (NT) and fertilized at the M rate during $1992-93$.

\begin{tabular}{|c|c|c|c|c|c|c|c|c|c|c|c|}
\hline \multirow[b]{2}{*}{ RS } & \multirow[b]{2}{*}{$\mathrm{N}$ rate } & \multicolumn{2}{|c|}{$\mathrm{ET}(\mathrm{mm})$} & \multicolumn{2}{|c|}{$\mathrm{CV}\left(\mathrm{m}^{3}\right)$} & \multicolumn{2}{|c|}{ RDW (kg) } & \multicolumn{2}{|c|}{$\mathrm{LN} \quad\left(\mathrm{mg} \cdot \mathrm{g}^{\mathrm{l}}\right)$} & \multicolumn{2}{|c|}{ FY (kg) } \\
\hline & & 92 & 93 & 92 & 93 & 92 & 93 & 92 & 93 & 92 & 93 \\
\hline \multirow[t]{3}{*}{$\overline{\mathrm{VL}}$} & $\mathbf{L}$ & $1580^{7}$ & 1226 & 4.0 & 6.7 & 3.6 & 7.0 & 21.1 & 18.4 & 27.5 & 5.7 \\
\hline & $\bar{M}$ & 1770 & 1639 & 4.7 & 9.3 & 3.1 & 4.6 & 23.9 & 25.0 & 58.3 & 82.1 \\
\hline & $\mathrm{H}$ & 2059 & 1989 & 7.4 & 12.6 & 4.3 & 4.4 & 24.1 & 26.6 & 46.6 & 96.1 \\
\hline \multirow[t]{3}{*}{ SO } & $\mathbf{L}$ & 1441 & 1095 & 3.1 & 5.3 & 2.3 & 2.3 & 23.9 & 20.1 & 8.6 & 48.1 \\
\hline & M & 1668 & 1838 & 5.0 & 8.4 & 2.8 & 3.7 & 24.0 & 25.1 & 11.6 & 76.0 \\
\hline & $\mathrm{H}$ & 1659 & 1376 & 4.7 & 8.8 & 2.5 & 3.5 & 26.8 & 25.9 & 14.9 & 63.9 \\
\hline VL & NT-M & $--y^{y}$ & & 5.8 & 11.1 & 3.7 & 5.0 & 23.7 & 23.7 & 36.5 & 72.2 \\
\hline \multirow[t]{8}{*}{ SO } & NT-M & & & 3.1 & 8.0 & 1.4 & 2.3 & 22.9 & 23.3 & 29.0 & 30.5 \\
\hline & Main effects & & & & & & & & & & \\
\hline & $\mathrm{N}$ rate & $* *$ & $* *$ & $* *$ & $* *$ & NS & NS & $*$ & *** & $*$ & $* *$ \\
\hline & RS & $* *$ & $* *$ & $* *$ & $* *$ & $*$ & $*$ & NS & NS & $*$ & NS \\
\hline & $\mathrm{N} \times \mathrm{RS}$ & NS & $* *$ & $*$ & NS & NS & NS & NS & NS & $*$ & $* *$ \\
\hline & $\mathrm{T}-\mathrm{NT}$ & & & NS & NS & NS & NS & NS & $*$ & NS & $*$ \\
\hline & RS & & & $* *$ & $*$ & $*$ & $*$ & NS & NS & $*$ & $*$ \\
\hline & $\mathrm{T} \times \mathrm{RS}$ & & & $*$ & NS & NS & NS & NS & NS & NS & NS \\
\hline
\end{tabular}

${ }^{\bar{z}}$ All values are means of three replicate tanks or trees; CV, RDW, and FY were evaluated in December, whereas LN was sampled in July. ${ }^{y}$ There was no no-tank ET data.

${ }^{\text {Ns, }, * * *}$ Nonsignificant or significant at $P<0.05$ or 0.01 . 
weight. At the end of 1992, the high-N trees on VL had the most roots but by the end of' 1993, low N trees on VL, which had the smallest canopies, had the largest fibrous root dry weight. There was no net root growth between 1992 and 1993 in low-N trees on SO rootstock.

Except for leaf N, all leaf nutritional values (data not shown) were within optimum ranges (Tucker et al., 1995). There were significant increases in leaf $\mathrm{N}$ concentration with $\mathrm{N}$ rate, but there was no effect of rootstock on leaf N (Table 2). By the end of 1993, medium $\mathrm{N}$ trees on both rootstock growing outside lysimeters had lower leaf $\mathrm{N}$ and lower yields than medium $\mathrm{N}$ trees in lysimeters. Based on leaf $\mathrm{N}$ concentration, low $\mathrm{N}$ trees on VL suffered $\mathrm{N}$ deficiency $\left(<20 \mathrm{mg} \cdot \mathrm{g}^{-1}\right)$ and their fruit yield was very low in 1993. Trees on VL generally had greater fruit yields than those on SO, even though this difference was not significant in 1993 due to the low yield of low-N trees on VL.

By 1993, there was a significant $(P<0.05)$ positive correlation $(r=0.58)$ between canopy volume and leaf $\mathrm{N}$ concentration when data from all trees $(n=24)$ were pooled. There was also a positive correlation between fruit yield and canopy volume $(r=0.64)$ and between canopy volume and ET $(r=0.91, \mathrm{n}=18)$, indicating that largest trees used the most water and had the highest yields regardless of treatment.

\section{Discussion}

Even though the irrigation and fertigation scheduling was intended to minimize drought and leaching from the largest trees, drainage water occasionally accumulated at the bottom of tanks for up to $24 \mathrm{~h}$ after a saturating rain. This water and any $\mathrm{N}$ in solution presumably would have been available for absorption by roots in the lysimeter tanks longer than for roots on trees outside the tanks. A high availability of water was reflected in ET values that are comparable to similar studies that varied depth to water table (Boman, 1994). Values of $\mathrm{N}$ leaching losses may, therefore, be lower than those in a commercial situation even in similar sandy soil. On the other hand, leaching losses from smaller trees probably was higher than necessary because of the irrigation rates, which were scheduled to meet the demands of largest trees. Any decrease in numbers of split applications of $\mathrm{N}$ or increase in irrigation rates above those used in this study would be expected to increase leaching losses.

Using frequent fertigation in this sandy soil, about $60 \%$ to $85 \%$ of the $\mathrm{N}$ (from $\mathrm{NH}_{4} \mathrm{NO}_{3}$ ) that was applied to the no-tree tank leached directly into groundwater. The average $\mathrm{N}$ concentration in these water samples (30 and $15 \mathrm{mg} \cdot \mathrm{liter}^{-1}$ ) exceeded the established acceptable maximum contamination limits of $10 \mathrm{mg} \mathrm{N} /$ liter. This underscores the importance of fertilizer placement where roots are most concentrated and where maximum $\mathrm{N}$ uptake can occur. This sandy soil stores very little N (Alva and Syvertsen, 1991). Thus, any losses of $\mathrm{N}$ attributable to volatilization or denitrification (Stevenson, 1986) from soil in the no tree tank could not have exceeded about $15 \%$ to $40 \%$ of the total $\mathrm{N}$ applied.

Although there may be relatively small differences in microbial $\mathrm{N}$ cycles in similarly fertilized soils with and without roots (Stevenson, 1986), the annual $\mathrm{N}$ uptake efficiencies of the medium $\mathrm{N}$ trees can be calculated from the difference between their $\mathrm{N}$ leaching losses and that from the no-tree tank. Medium $\mathrm{N}$ rate trees on VL took up about $83 \%$ (85\% minus $2 \%$ ) and $54 \%$ of the $\mathrm{N}$ applied during 1992 and 1993 or about $68 \%$ averaged over the 2year period. Trees on SO took up $72 \%$ and $51 \%$. or an average of about $61 \%$. These values span the range of previously measured $\mathrm{N}$ uptake efficiencies (Dasberg, 1987; Syvertsen et al., 1993) and underscore the higher uptake efficiencies by the more vigorous rootstock. Nitrogen uptake efficiency decreased when application rates were increased between 1992 and 1993. Since the percentage of $\mathrm{N}$ leached increased between medium and high $\mathrm{N}$ treatments, $\mathrm{N}$ uptake efficiency also probably decreased at high $\mathrm{N}$ rates.

There was a limitation of growth of trees on VL by the medium $\mathrm{N}$ rate during 1992 (33\%. of recommended) that could have carried over from 1992 to 1993 . Based on canopy development, fibrous root weight, and fruit yield in 1993; however, even the medium rate in 1993 (85\% of recommended) was low enough to limit the growth of trees on VL. Coupled with leaching losses, the recommended rate in 1992 appeared to be appropriate for trees on VL. The $31 \%$ and $78 \%$ of the recommended rate applied to trees on SO did not limit growth or yield. Consequently, recommended rates could be reduced by $69 \%$ for 5 -year-old trees and $22 \%$ for 6 -yearold trees on SO without loss of growth or yield.

The lower $\mathrm{N}$ requirement by slower-growing trees on $\mathrm{SO}$ was reflected in higher leaching losses from trees on SO than from trees on VL. Low-N trees on VL, which had become N deficient, had the smallest canopies but the greatest fibrous root dry weight. We previously have seen this pattern of growth allocation to roots at the expense of canopy growth in salt stressed trees (Syvertsen et al., 1993). Root growth can also be increased after reducing the internal competition for carbon by fruit after removing very young green fruit (Duncan and Eissenstat, 1993) or, in this case, after limiting fruit production by $\mathrm{N}$ deficiency stress.

Although the lysimeter tanks had no significant effect on root or canopy growth (Table 2), trees outside tanks in 1993 had lower leaf $\mathrm{N}$ and fruit yield than medium-N-rate trees in tanks. Yield of SO trees was increased by growing in tanks in 1992 . We did not attempt to measure water use by trees growing outside tanks but trees on SO apparently benefited more from growing in the tanks than did trees on VL.

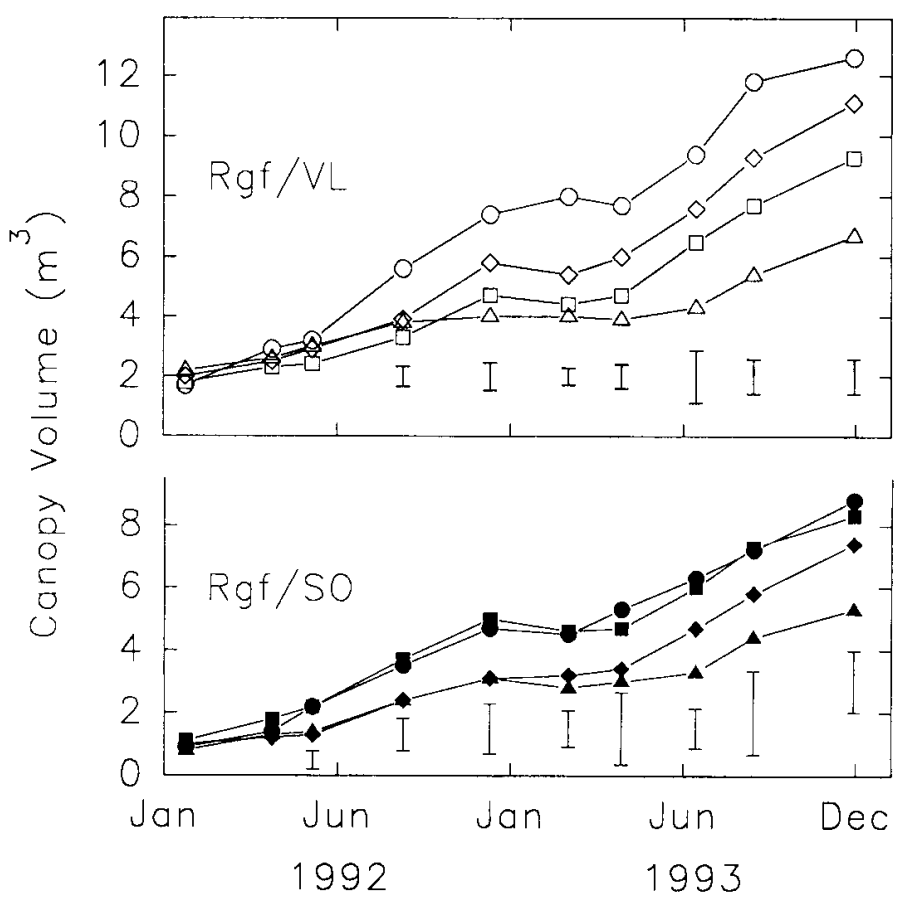

Fig. 5. Canopy volumes $\left(\mathrm{m}^{3}\right)$ for-5- and 6-year-old 'Redblush' grapefruit (Rgf) trees on 'Volkamer' lemon (VL, open symbols) or sour orange (SO, closed symbols) rootstock grown in lysimeter tanks and fertilized at the high $(\bullet, \bigcirc)$, medium ( $\mathbf{\square}$, $\square)$, or low $(\boldsymbol{\Delta}, \Delta) \mathrm{N}$ rate $(\mathrm{n}=3)$ along with no-tank $(\diamond \diamond)$ trees fertilized at the medium rate during 1992 and 1993. Each point is the mean of $n=3$; statistical analysis of December 1992 and 1993 appear in Table 2. 
Plants that have relatively low $\mathrm{N}$ can take up available $\mathrm{N}$ more efficiently than plants that have high N (Marschner, 1986). Large concentration gradients of $\mathrm{N}$ between roots and soil can exist when roots are deficient. In citrus trees, a larger percentage of applied $\mathrm{N}$ is removed with harvested fruit when trees have been fertilized at low than high $\mathrm{N}$ rates (Smith, 1966a). However, our data did not show high $\mathrm{N}$ uptake efficiency at conditions of low plant $\mathrm{N}$. Based on leachate data in 1993, low $\mathrm{N}$ trees on SO absorbed a smaller percentage of the smaller amount of $\mathrm{N}$ applied than the medium$\mathrm{N}$ trees on SO (Table 1). Similarly, low-N trees on VL with high fibrous root densities also took up a smaller percentage of the applied $\mathrm{N}$ than medium- $\mathrm{N}$ trees on VL with sufficient $\mathrm{N}$. The relatively high irrigation rates, which were not modified for differences in ET, may have contributed to the high percentages of $\mathrm{N}$ leaching at the low $\mathrm{N}$ rates. These results underscore the importance of considering fertilizer and irrigation practices in concert. Any efforts to minimize N leaching losses by allowing trees to become $\mathrm{N}$ deficient to the point where shoot growth is reduced may be futile if irrigation rates are not reduced accordingly.

When growing citrus on sandy soils that are vulnerable to leaching, a small amount of $\mathrm{N}$ leaching into groundwater probably is unavoidable (Dasberg, 1987). The relatively low concentrations of $\mathrm{N}$ in the drainage water from most of these lysimeters, however, show that citrus can be grown in the sandy soils of central Florida with only minimum contamination of groundwater $(<10 \mathrm{mg} \mathrm{N} /$ liter) if best management practices are followed and reduced $\mathrm{N}$ application rates are used. Fertilizer rates and irrigation practices can be modified for trees on different rootstock to minimize $\mathrm{N}$ leaching losses if tree growth and leaf $\mathrm{N}$ concentrations are considered.

Tree growth, water use, yield, and $\mathrm{N}$ uptake were closely related and, along with $\mathrm{N}$ application rate, determined leaching losses. Together, these results indicated that currently recommended rates of $\mathrm{N}$ were $22 \%$ to $69 \%$ too high for young grapefruit trees on SO. Although excessively high $\mathrm{N}$ rates applied to trees on VL increased canopy size and leaf $\mathrm{N}$ concentrations over that of medium $\mathrm{N}$ trees on VL, comparable yields and higher leaching losses from high $\mathrm{N}$ trees suggested that average recommended rates were adequate for these trees.

\section{Literature Cited}

ALPKEM Corporation. 1986. Rapid flow analyzer methodology for nitrate and nitrite nitrogen. A303-S170. ALPKEM Corp., Clackamas, Ore.

ALPKEM Corporation. 1989. Rapid flow analyzer methodology for ammonia nitrogen. A303-S020. ALPKEM Corp., Clackamas, Ore.

Agren, G.I. 1985. Theory for growth of plants derived from the nitrogen productivity concept. Physiol. Plant. 64:17-28.

Albrigo, L.G., C.A. Anderson, G.J. Edwards, F.W. Bistline, W.J. Hepburn, and T. Cary. 1975. Yield estimates of 'Valencia' orange research plots and groves. Proc. Fla. State Hort. Soc. 88:44-49.

Alva, A.C. and J.P. Syvertsen. 1991. Irrigation water salinity affects soils nutrient distribution, root density and leaf nutrient levels of citrus under drip fertigation. J. Plant Nutr. 14:715-727.

Boman, B.J. 1994. Evapotranspiration by young Florida flatwoods citrus trees. J. Irr. Drain. Eng. 120:80-88.

Boman, B.J. and J.P. Syvertsen. 1991. Drainage lysimeters for high water table citrus studies, p. 318-325. In: R.G. Allen, T.A. Howell, W.O. Pruitt, I.O. Walter, and M.E. Jensen (eds.). Lysimeters for evapotranspiration and environmental measurements. Proc. ASCE Ind. Symp. Lysimetry, ASCE, New York.

Castle, W.S., D.P.H. Tucker, A.H. Kregdorn, and C.O. Youtsey. 1993. Rootstock for Florida citrus. 2nd ed. SP-42. Inst. Food Agr. Sci., Univ. Fla., Gainesville.

Dasberg, S. 1987. Nitrogen fertilization in citrus orchards. Plant and Soil 100:1-9.

Dasberg, S., H. Bielorai, A. Haimowitz, and Y. Erner, 1991. The effect of saline irrigation water on "Shamonti" orange trees. Irr. Sci. 12:205-211.

Duncan, L.W. and D.M. Eissenstat. 1993. Response of Tylenchulus semipenetrans to citrus fruit removal: Implications for carbohydrate competition. J. Nematol. 25:7-14.

Feigenbaum, S., H. Bielorai, Y. Erner, and S. Dasberg. 1986. The fate of ${ }^{15} \mathrm{~N}$ labeled nitrogen applied to mature citrus trees. Plant Soil 97: 179187.

Hanlon, E.A. and J.M. DeVore. 1989. IFAS extension soil testing laboratory chemical procedures and training manual. Inst. Food Agr. Sci., Univ. Fla., Circ. 812, Gainesville.

Kate, T. 1986. Nitrogen metabolism and utilization in citrus, p. 8 I -2 16. In: J. Janick (cd.). Horticultural reviews. vol. 8. AVI Publishing Co.

Marschner, H. 1986. Mineral nutrition and yield responses, p. 155-172. In: Mineral nutrition of higher plants. Academic Press, New York.

Reuther, W. (cd.). 1973. The citrus industry. vol. 3. Production technology, Univ. of California Press, Agr. Sci. Publ., Berkeley. p. 448-474.

Riotte, W. 1994. Ridge citrus water quality project annual (1993) report. Fla. Dept. Agr. Consum. Serv., Tallahassee.

Smith, P.F. 1966a. Citrus nutrition, p. 174-207. In: N.F. Childers (cd.). Nutrition of fruit crops. Hort. Publ., Rutgers, N.J.

Smith, P.F. 1966b. Leaf analysis of citrus, p. 208-228. In: N.F. Childers (cd.). Nutrition of fruit crops. Hort. Publ., Rutgers, N.J.

Stevenson, F.J. 1986. The internal cycle of nitrogen in soil, p. 155-216. In: Cycles and soil: carbon, nitrogen, phosphorus, sulfur, micronutrients. Wiley, New York.

Syvertsen, J.P. and J. Lloyd. 1994. Citrus, p. 65-99. In: B. Schaffer and P. Andersen (eds.). Handbook of environmental physiology of fruit crops. vol. 2. Sub-tropical and tropical crops. CRC Press, Boca Raton, Fla.

Syvertsen, J.P., M.L. Smith, and B.J. Boman. 1993. Tree growth, mineral nutrition and nutrient leaching losses from soil of salinized citrus. Agr. Ecosyst. Environ. 45:319-334.

Tucker, D. P. H., A.K. Alva, L.K. Jackson, and T.A. Wheaton (eds.). 1995. Nutrition of Florida citrus trees. SP-169. Univ. of Florida, Gainesville. Whitney, J. D., A. Elezaby, W.S. Castle, T.A. Wheaton, and R.C. Littell. 1991. Citrus tree spacing effects on soil water use, root density and fruit yield. J. Amer. Soc. Agr. Eng. 34:129-134.

Willis, L.E., F.S. Davies, and D.A. Graetz. 1990. Fertilization, nitrogen leaching and growth of young 'Hamlin' orange trees on two rootstock. Proc. Fla. State Hort. Soc. 103:30-37. 